\title{
Distance learning in the digital era
}

\author{
Epriyanti Epriyanti ${ }^{1}$, Nur Ahyani ${ }^{2}$, Nila Kusumawati ${ }^{2}$ \\ ${ }^{1}$ Sekolah Menengah Atas Negeri 2 OKU, Indonesia \\ ${ }^{2}$ Universitas PGRI Palembang, Indonesia
}

\section{Article Info \\ Article history: \\ Received Jul 20 $0^{\text {th }}, 2021$ \\ Revised Aug $12^{\text {th }}, 2021$ \\ Accepted Aug 30 $0^{\text {th }}, 2021$ \\ Keyword: \\ Distance Learning \\ Digital Era \\ Learning From Home \\ Online.}

\begin{abstract}
The Covid 19 pandemic makes the learning process must be done remotely. The learning process, which is usually done face-to-face, changes to a distance. There are many new things in distance learning. Adaptations are carried out by teachers and students. Increased mastery of technology is carried out. This research uses the library research method, where this research in collecting information and data uses a variety of materials and materials in the library, namely in the form of books, journals, documents, magazines, historical stories, news, and other relevant sources. Distance learning requires adequate facilities and infrastructure, such as laptops, computers, smartphones and internet networks. This becomes one of the challenges of distance learning. Distance learning makes students more independent, because it places more emphasis on being student centered. They are more courageous to express their opinions and ideas. As well as the government has also provided several platforms that students can use to learn.
\end{abstract}

(C) 2021 The Authors. Published by IICET.

This is an open access article under the CC BY-NC-SA license (https://creativecommons.org/licenses/by-nc-sa/4.0

\section{Corresponding Author:}

Epriyanti, E.,

Sekolah Menengah Atas Negeri 2 OKU, Indonesia

Email: epriyanti181@gmail.com

\section{Introduction}

The United Nations or PBB that one of the sectors affected by the Covid 19 pandemic is the world of education. The United Nations or the United Nations states that one of the sectors affected by the Covid 19 pandemic is the world of education [1]. This has led several countries to decide to close schools and universities. In an effort to prevent the spread of covid 19, the World Health Organization (WHO) recommends temporarily stopping activities that could potentially cause crowds. Even during the outbreak of Covid 19 in Indonesia, there were many ways that the government did to prevent the spread, one of which was social distancing. Then issued a Circular of the Ministry of Education and Culture (Kemendikbud) of the Directorate of Higher Education No. 1 of 2020 concerning preventing the spread of covid 19 in the world of education. In this circular, the Ministry of Education and Culture instructs to organize distance learning and advises students to learn from their homes.As of March 2020, the impact that Covid 19 has had on teaching and learning activities has been quite pronounced, this can be seen from learning that should have been done directly and meaningfully now can only be done independently. That way students do indirect learning by utilizing online or online learning which is considered quite effective in situations like today.

Distance learning itself can be understood as formal education organized by schools where students and teachers are in separate locations so it requires an interactive telecommunication system to connect the two [2]. The impact of the covid 19 outbreak has not subsided, learning will continue to be carried out from each home (distance learning). One alternative to keep learning going is online learning. Moore et al [3] state that 
online learning is a learning activity that requires an internet network with connectivity, accessibility, flexibility, and the ability to generate various types of learning interactions. [4] show that the use of the internet and multimedia technology is able to change the way of conveying knowledge and can be an alternative to learning carried out in the classroom.

The implementation of online learning requires supporting facilities, such as smartphones, laptops, or tablets that can be used to access information anywhere and anytime [5]. In Indonesia itself, there are several applications provided by the government to support learning activities at home. In addition, an educator can face to face with students through an application that can be accessed by an internet network. However, some of the obstacles that exist in online learning make students less interested in online learning.

This study aims to identify online learning activities where students can access learning as an effort to support government programs, namely distance learning during the COVID-19 pandemic and students' responses to online learning during school. The subjects of this study were students who did distance learning during school.

\section{Method}

This research uses the library research method, where this research in collecting information and data uses a variety of materials and materials in the library, namely in the form of books, journals, documents, magazines, historical stories, news, and other relevant sources. [16]. Meanwhile, according to [17] literature is a reference, theoretical study, scientific literature, and other references that have a connection with values, culture, and norms that developments in the social situation under study. The object of this research is online learning which is done in each house. With this method, it is expected to be able to identify online learning activities at the homes of students as an effort to support government programs, namely distance learning.

\section{Results and Discussions}

This research uses the library research method, where this research in collecting information and data uses a variety of materials and materials in the library, namely in the form of books, journals, documents, magazines, historical stories, news, and other relevant sources [16]. Meanwhile, according to [17] literature is a reference, theoretical study, scientific literature, and other references that have a connection with values, culture, and norms that developments in the social situation under study. The object of this research is online learning which is done in each house. With this method, it is expected to be able to identify online learning activities at the homes of students as an effort to support government programs, namely distance learning.

As long as the Covid 19 outbreak entered Indonesia, there were several government regulations issued to prevent the spread of the outbreak. One of the things that is being encouraged is the existence of social distancing. Social distancing is an effort to maintain a distance, for example, such as avoiding crowds and physical contact. The existence of social distancing is clearly very influential in the world of education. Learning carried out at schools has been closed starting March 2020. Even up to January 2021, learning is still being carried out from each house. In accordance with the Health Quarantine Law Article 59 Paragraph 3 of 2020 explains that "these large-scale social restrictions include at least school and work vacations, restrictions on religious activities, and / or restrictions on activities in public places or facilities."

The challenge itself is in the world of education so that learning can continue in the midst of the Covid 19 pandemic. One way out to deal with this problem is learning to be done online. Online learning is learning that is done remotely with the help of the internet. In online learning, facilities and infrastructure are needed, in the form of laptops, computers, smartphones, and internet network assistance. In addition to facilities and infrastructure, a teacher must also be able to adapt to the situation of students. [18] states that "teachers must be able to develop the teaching profession and carry out their duties by adjusting the needs of students and learning materials that keep up with the times." In 2018, 62.41\% of Indonesia's population owned cellular phones and $20.05 \%$ of households had computers. This data is very relevant to the results of research which shows that although there are students who do not have laptops, almost all of them already have smartphones.

One of the challenges with online learning is the expertise in the use of technology on the part of both educators and students. Dabbagh [19]. States that the characteristics of students in online or online learning activities are: (1) learning enthusiasm; (2) literacy of technology; and (3) interpersonal communication skills.

Learning enthusiasm: student enthusiasm during the learning process is strong or high for independent learning. When learning online, the criteria for the completeness of understanding the material in learning are 
determined by the student himself. Knowledge will be found by themselves and students must be independent. So that the independent learning of each student makes a difference in different learning success.

Literacy of technology: in addition to independence for learning activities, the level of student understanding of the use of technology. When online learning is one of the successes of doing online learning. Before online learning students must master the technology to be used. The tools commonly used as a means of online learning are computers, smartphones, and laptops. The development of technology in the 4.0 era has created many applications or features that are used as a means of learning online.

Interpersonal communication skills: In these characteristics students must master communication skills and interpersonal skills as one of the conditions for success in online learning. Interpersonal skills are needed to establish relationships and interactions between other students. As social beings, they still need interaction with other people even though online learning is carried out independently. Therefore, interpersonal skills and skills in communication must still be trained in social life.4. Collaborate: understand and use interaction and collaborative learning. Students must be able to interact between other students or with lecturers in a forum that has been provided, because in online learning it is the students themselves.

This interaction is necessary, especially when students have difficulty understanding the material. Apart from this, interactions also need to be maintained in order to train their social spirit. So that the spirit of individualism and anti-socialism is not formed by students. With online learning, students are also able to understand collaborative learning. Students will also be trained to be able to collaborate either with the surrounding environment or with various systems that support online learning.5. Skills for independent study: one of the characteristics of online learning is the ability to learn independently. Independent learning is indispensable in online learning. Because during the learning process, students will look for, find and conclude what they have learned. "Independent learning is a process where students are directly involved in identifying what needs to be learned to be in control of the learning process" [20]. When learning independently, motivation is needed to support the success of the learning process online.

Several studies have shown that many students use laptops and smartphones in learning. The ability of laptops and smartphones to access the internet allows students to take part in teaching and learning activities carried out in the form of video conferences or those carried out in online classes using learning application services available online [21].

The online learning process has been carried out by giving assignments via WhatsApp, video conferencing, Google Forms, or through special applications available. However, one of the vocational high school students in Surabaya admitted that he often received assignments via WhatsApp, then wrote them in books and photographed them to send to teachers. For video conferencing activities are also scheduled, held twice a week for discussion. An assignment through the google form application is also carried out, where after completing the task the value will immediately appear. But online learning also has its challenges. One of them is the availability of the internet network. Some admit that it is difficult to take part in online learning because not all regions have an internet network with smooth access [22].

This makes it difficult for them to collect assignments. Apart from the challenges regarding internet services, another challenge is the cost constraint. To take part in online learning, students have to pay more to buy internet quotas. Especially when learning is done via video conference, it will use up a lot of internet quota. Based on information from Din published on May 25, 2020, it is stated that data consumption for video conferencing using a zoom application with video quality 720P for one hour consumes $540 \mathrm{MB}$ of data. Another thing that must be considered in using smartphones to support online learning is the addiction to use smartphones. Several studies have shown indications of gadget addiction due to overuse. So that it can raise concerns about negative effects on the use of gadgets and social media, such as the possibility of being exposed to wrong information and inattention during learning due to playing the social media. In addition, people who are addicted to gadgets tend to have social and academic problems [23]. So research shows that most students prefer to return to school immediately.

However, online learning is the only solution to suppress the spread of covid 19. Covid 19 is a disease that is very easy to spread, where the virus specifically attacks the human respiratory system [24]. Controlling infectious diseases can be done by minimizing contact between infected people and people who are susceptible to infection [25]. Maintaining a distance to reduce physical contact that has the potential to transmit disease is known as social distancing [26]. In online learning, students feel more comfortable asking questions and expressing opinions in forums that are carried out online [27]. [28] stated that online learning is more studentcentered so that it can bring out the responsibility and autonomy of students in learning. So as to make students more able to foster independence in learning. 


\section{Conclusions}

Distance learning is one of the solutions for implementing social distancing to prevent the spread of the Covid 19 outbreak. Distance learning is one of the consequences of the Covid 19 outbreak, which causes learning that is usually carried out in schools to become learning at home. Distance learning requires adequate facilities and infrastructure, such as laptops, computers, smartphones and internet networks. This becomes one of the challenges of distance learning. Distance learning makes students more independent, because it puts more emphasis on being student centered. They are more courageous to express their opinions and ideas. As well as the government has also provided several platforms that students can use to learn.

\section{References}

Purwanto. (2020). Studi Eksploratif Dampak Pandemi COVID-19 Terhadap Proses Pembelajaran Online di Sekolah Dasar. Journal of Education, Psychology, and Counselling. Volume 2 No. 1.

Hamidaturrohmah., Mulyani, T., (2020), Strategi Pembelajaran Jarak Jauh Siswa Berkebutuhan Khusus Di SD Inklusi Era Pandemi Covid-19. Elementary. 8(2), 247 - 278.

Firman., \& Sari. (2020). Pembelajaran Online di Tengah Pandemi Covid-19. Indonesian Journal Of Educational Science (IJES), Volume 02 No 02.

Zhang, et al. (2004). Can e-learning replace classroom learning? Communications of the ACM.Vol. 47 No.5.

Gikas, J., \& Grant, M. M. (2013). Mobile computing devices in higher education: Student perspectives on learning with cellphones, smartphones \& social media. Internet and Higher Education. Vol. 19 Pages 18-26.

Kuntarto, E. (2017). Keefektifan Model Pembelajaran Daring Dalam Perkuliahan Bahasa Indonesia di Perguruan Tinggi. Jurnal Indonesian Language Education and Literature (ILEaL), ISSN (Onine) Vol.3 No.1: 25022261.

Rizki Setiawan, Eti Komalasari. (2020). Membangun Efektifitas Pembelajaran Sosiologi di Tengah Pandemi Covid19, Edusocius Jurnal Ilmiah Penelitian Pendidikan dan Sosiologi, 4(1).

Baharin, R., Syah Aji, R., Yussof, I., Mohd Saukani, N. (2020). Impact of Human Resource Investment on Labor Productivity in Indonesia. Iranian Journal of Management Studies, 13(1), 139-164. doi: 10.22059/ijms.2019.280284.673616.

Aji, R. (2020). Dampak Covid-19 pada Pendidikan di Indonesia: Sekolah, Keterampilan, dan Proses Pembelajaran. SALAM: Jurnal Sosial dan Budaya Syar-i, 7(5), 395-402. doi:https://doi.org/10.15408/sjsbs.v7i5.15314

Baharin, R., Syah Aji, R., Yussof, I., \& Mohd Saukani, N. (2020). Impact of Human Resource Investment on Labor Productivity in Indonesia. Iranian Journal of Management Studies, 13(1), 139-164. doi: 10.22059/ijms.2019.280284.673616

Yerusalem, M. R., \& dkk. (2020). Desain dan Implementasi Sistem Pembelajaran Jarak Jauh Di Program Studi Sistem Komputer. Jurnal Teknologi dan Sistem Komputer. Vol 3 No. 4 (2015). https: //jtsiskom.undip.ac.id/index. php/ jtsiskom /article/view/ 12668 DOI: https ://doi.org/10.14710/ jtsiskom.3.4.2015.481-492.

Munir. (2012). Pembelajaran Jarak Jauh Berbasis Teknologi Informasi dan Komunikasi. Bandung: Alfabeta.

Kusniyah., \& Hakim, L. (2019). Efektifitas Pembelajaran Berbasis Daring: Sebuah Bukti pada Pembelajaran Bahasa Inggris. Jurnal Pemikiran dan Penelitian Pendidikan, Vol. 17 No.1.

Martins, M. de L. (2015). How to Effectively Integrate Technology in the Foreign Language Classroom for Learning and Collaboration. Procedia - Social and Behavioral Sciences. Vol. 174, 77-84.

Sofyana \& Abdul. (2019). Pembelajaran Daring Kombinasi Berbasis Whatsapp Pada Kelas Karyawan Prodi Teknik Informatika Universitas PGRI Madiun. Jurnal Nasional Pendidikan Teknik Informatika. 8(1), 81-86.

Dewi, Wahyu Aji Fatma. (2020). Dampak Covid-19 Terhadap Implementasi Pembelajaran Daring Di Sekolah Dasar. Edukatif: Jurnal Ilmu Pendidikan. Volume 2 Nomor 1 Halm 55-61.

Sugiyono. (2012). Metode Penelitian Kuantitatif Kualitatif dan R\&D. Alfabeta.

Wulandari. (2018). Peningkatan Kompetensi Profesional Guru Kewirausahaan melalui Lesson Study Berbasis Pantai dan Laut. JPE (Jurnal Pendidikan Edutama), Vol. 5 No. 2.

Hasanah, dkk. (2020). Analisis Aktivitas Belajar Daring Mahasiswa Pada Pandemi COVID-19. Jurnal Pendidikan. Volume 1 No.1.

Hasanah, dkk. (2020). Analisis Aktivitas Belajar Daring Mahasiswa Pada Pandemi COVID-19. Jurnal Pendidikan. Volume 1 No.1.

Firman \& Sari. (2020). Pembelajaran Online di Tengah Pandemi Covid-19. Indonesian Journal Of Educational Science (IJES), Volume 02 No 02.

Hasanah, dkk. (2020). Analisis Aktivitas Belajar Daring Mahasiswa Pada Pandemi COVID-19. Jurnal Pendidikan. Volume 1 No.1.

Kwon, M., Lee, J. Y., Won, W. Y., Park, J. W., Min, J. A., Hahn, C., ... Kim, D. J. (2013). Development and Validation of a Smartphone Addiction Scale (SAS). PLoS ONE. Vol. 8 No.2. 
Rothan, H. A., \& Byrareddy, S. N. (2020). The Epidemiology and Pathogenesis of Coronavirus Disease (Covid-19) Outbreak. Journal of Autoimmunity, Volume 109 No. 1-4.

Caley, P., Philp, D. J., \& Mccracken, K. (2008). Quantifying Social Distancing Arising from Pandemic Influenza. Journal of The Royal Society Interface, Vol. 5, 631-639.

Bell, D., et al. (2006). Nonpharmaceutical Interventions for Pandemic Influenza, National and Community Measures. Emerging Infectious Diseases Journal. Vol. 12 No. 1.

Firman \& Sari. (2020). Pembelajaran Online di Tengah Pandemi Covid-19. Indonesian Journal Of Educational Science (IJES), Volume 02 No 02.

Kuo, et al. (2014). Interaction, Internet self-efficacy, and self-regulated learning as predictors of student satisfaction in online education courses. Volume 20, pages 35-50 